Transnational Corporations and Transnational Governance 
This page intentionally left blank 


\section{Transnational Corporations and Transnational Governance}

The Costs of Crossing Borders in the Global Economy

Edited by

Sarianna Lundan

University of Bremen, Germany

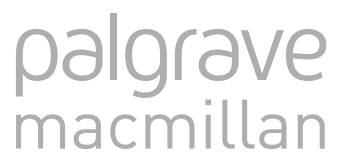




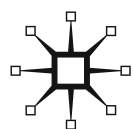

Selection, introduction and editorial content @ Sarianna Lundan 2015 Individual chapters (C) Contributors 2015

Softcover reprint of the hardcover 1st edition 2015 978-1-137-46767-6

All rights reserved. No reproduction, copy or transmission of this publication may be made without written permission.

No portion of this publication may be reproduced, copied or transmitted save with written permission or in accordance with the provisions of the Copyright, Designs and Patents Act 1988, or under the terms of any licence permitting limited copying issued by the Copyright Licensing Agency, Saffron House, 6-10 Kirby Street, London EC1N 8TS.

Any person who does any unauthorized act in relation to this publication may be liable to criminal prosecution and civil claims for damages.

The authors have asserted their rights to be identified as the authors of this work in accordance with the Copyright, Designs and Patents Act 1988.

First published 2015 by

PALGRAVE MACMILLAN

Palgrave Macmillan in the UK is an imprint of Macmillan Publishers Limited, registered in England, company number 785998, of Houndmills, Basingstoke, Hampshire RG21 6XS.

Palgrave Macmillan in the US is a division of St Martin's Press LLC, 175 Fifth Avenue, New York, NY 10010.

Palgrave Macmillan is the global academic imprint of the above companies and has companies and representatives throughout the world.

Palgrave ${ }^{\circledR}$ and Macmillan ${ }^{\circledR}$ are registered trademarks in the United States, the United Kingdom, Europe and other countries

ISBN 978-1-349-50003-1

ISBN 978-1-137-46769-0 (eBook)

DOI $10.1057 / 9781137467690$

This book is printed on paper suitable for recycling and made from fully managed and sustained forest sources. Logging, pulping and manufacturing processes are expected to conform to the environmental regulations of the country of origin.

A catalogue record for this book is available from the British Library.

Library of Congress Cataloging-in-Publication Data

Transnational corporations and transnational governance: the cost of crossing borders in the global economy / edited by Sarianna Lundan, University of Bremen, Germany.

pages $\mathrm{cm}$

Summary: "Expanding the economic footprint of the firm comes at the cost of a corresponding increase in the complexity of coordination. Transnational Corporations and Transnational Governance examines the different kinds of distance-related barriers related to cross-border investment. Different forms of governance, whether inside the firm or as part of its network of external relationships, have the aim of reducing uncertainty and creating a more predictable environment. The chapters in this volume explore the impact of conventional distance-related barriers, as well as the more difficult institutional barriers reflecting differences in norms and beliefs, on the costs and methods of coordination adopted by multinational firms." - Provided by publisher.

1. International business enterprises. 2. Corporate governance.

3. International business enterprises-Management. I. Lundan, Sarianna M. HD2755.5.T67968 2015

338.8 ' $-\mathrm{dc} 23$ 


\section{Contents}

List of Figures vii

List of Tables $\quad$ viii

Acknowledgements $\quad \mathrm{x}$

Notes on Contributors $\quad$ xi

1 The Costs of Crossing Borders in the Global Economy 1 Sarianna Lundan

Part I Behavioural Assumptions in the Theory of the TNC

2 A Transaction Cost Theory of the TNC 25 Jean-François Hennart

3 Bounded Reality: A New Behavioral Foundation for MNE Governance

Alain Verbeke and Nathan S. Greidanus

4 The 'Parenting Advantage' and Innovation Processes in the Multinational Firm: Does Top Management Mess Things Up? Mats Forsgren

Part II The Footprint of the TNC: The Role of Borders and Distance

5 Distance-Related Barriers and the Internationalization of Finnish MNEs

Sarianna Lundan

6 Looking into the Innovation Process: How International Is Innovation in Multinational Companies? Jannika Mattes

7 Locations of Corporate Headquarters in Europe: Between Inertia and Co-evolution 
Part III Managing Cross-Border Interdependencies

8 Intra-Firm Trade Law: Contract Enforcement and Dispute Resolution in Transnational Corporations Gralf-Peter Calliess and Stephan von Harder

9 Competence Building in Transnational Companies: The Role of Regional Headquarters in Subsidiary Coordination Jörg Freiling and Sven Laudien

10 The Evolution of a Regional Headquarters Population: An Ecological Analysis

Perttu Kähäri and Rebecca Piekkari

\section{Part IV TNCs as Institutional Entrepreneurs}

11 Accounting Firms: Global Reach without Transnational Form

Jochen Zimmermann and Jan-Christoph Volckmer

12 Operationalising the UN Business and Human Rights Framework: The Corporate Responsibility to Respect Human Rights and Due Diligence Peter Muchlinski

13 The Changing Role of Business in Global Society: Implications for Governance, Democracy, and the Theory of the Firm

Andreas Georg Scherer, Guido Palazzo, and Hannah Trittin 


\section{List of Figures}

2.1 Two alternative methods to organize an interdependency 28

4.1 The relationship between MNC headquarters' involvement in development and transfer of innovations at the subsidiary level and the efficiency of the development and transfer processes

4.2 Optimistic and pessimistic views on the role of headquarters in the innovation processes at the subsidiary level

5.1 Parent entropy by turnover

5.2 Total and regional entropy (seven regions)

5.3 Distance measures in relation to parent internationalization (foreign assets/total assets)

5.4 Distance measures in relation to parent total assets

7.1 Regional distribution of the 1,000 companies with the highest R\&D expenditures in the EU (2008)

8.1 Hierarchical dispute resolution in decentralised firms

9.1 Modified open system view 257

9.2 The extended learning process of Crossan et al. (1999) 262

10.1 Age structure of the RHQ population in Finland between 1969 and 1998

11.1 Organisational chart of the different types of corporations 


\section{List of Tables}

2.1 Organizing methods: hierarchy vs. the price system 30

2.2 Forms taken by the foreign expansion of TNCs 35

2.3 Optimal assignment of equity in a foreign host market 43

3.1 Prevalence of bounded reliability examples in MNE cases 72

3.2 Sources of BRel and economizing mechanisms 80

5.1 Descriptive statistics 133

5.2 Pairwise correlations and significance level 134

5.3 Quartile groups based on parent internationalization (foreign assets/total assets) 136

5.4 Quartile groups based on parent total assets 137

6.1 Characteristics of different ideal-typical forms of internationalisation

6.2 Characteristics of the investigated innovation projects 155

6.3 Internationalisation setup in a project in AutoCom 157

6.4 Internationalisation setup in a project in TransportCom 159

6.5 Internationalisation setup in a project in PharmaCom 160

6.6 Internationalisation setup in a project in ITCom 162

6.7 Forms of internationalisation in the investigated
innovation projects

6.8 Internationalisation setups in the different arenas 167

7.1 Economic and technological inequalities in the 270 NUTS2 regions of the EU 27 (1995-2009)

7.2 Corporate headquarters and their regional environment: two types of locational patterns

7.3 Regional variables used for explaining the location of corporate headquarters 
7.4 Description of regional variables

7.5 Regional distribution of 1,000 EU MNC companies investing the largest sums in R\&D (2008)

7.6 A typology of European NUTS2 regions and the regional distribution of $\mathrm{R} \& \mathrm{D}$ top investors: the results of a hierarchical cluster analysis

7.7 Binary logistic regressions predicting the presence of at least one of the 1,000 top R\&D investing companies in a European region and multiple regressions predicting the number of companies (NUTS2 level, 2008)

10.1 Two phases of data collection in 1998 and 2010

10.2 RHQ traits under the processes of variation and retention in the RHQ population

10.3 Changes in the RHQ population 1998-2010

10.4 Ecological processes and their interactions with the RHQ population across three ecologies

11.1 TNI ratios for the Big 4 accounting firms

11.2 Self-image of the Big 4 accounting firms

11.3 International membership in boards and management

11.4 International staff transfer

11.5 Intercompany comparison of chosen auditors

13.1 Characteristics of the instrumental and the new political approach to CSR 


\section{Acknowledgements}

This volume brings together a collection of 13 chapters examining the various costs related to crossing borders in the global economy. The contributions were drawn from a lecture series that was held under the auspices of the Center for Transnational Studies (ZenTra) at the University of Bremen during the academic year 2011-2012. While the focus of this volume is on the cross-border activities of firms that are often designated as multinational, we employ the term transnational to help us link to other discourses in the social sciences, such as those examining the emergence and significance of transnational networks of professionals, diaspora communities, civil society groups or the development of de facto transnational law.

I wish to extend my thanks to the staff and students working for the Chair in International Management and Governance for the organization of the original lecture series. Particular thanks are due to Dr. Sigrid Kannengießer and Dr. Tilo Halaszovich of ZenTra for their professional assistance in reviewing and editing the contributions included in this book. Thanks are also due to Liz Barlow of Palgrave for her support and enthusiasm for this project.

Chapter 3 is reproduced with the kind permission of Palgrave from Verbeke, A. \& Greidanus, N. S. (2009). The end of the opportunism vs. trust debate: Bounded reliability as a new envelope concept in research on MNE governance, Journal of International Business Studies, 40(9): 1471-95. Chapter 13 is a revised, updated and shortened version of a paper that has been published previously as Scherer, A. G. \& Palazzo, G. (2011). The new political role of business in a globalized world: A review of a new perspective on CSR and its implications for the firm, governance and democracy, Journal of Management Studies, 48(4): 899-931. Additionally, the authors wish to acknowledge the financial support of ETLA - the Research Institute of the Finnish Economy for Chapter 5. 


\section{Notes on Contributors}

Nina Baur is Professor of Methods of Social Research, Technical University Berlin. She is a member of the DFG Graduate College 'Innovation Society Today'. Her research interests include qualitative and quantitative methods of social research, economic sociology (labour markets, consumer goods markets), spatial sociology, sociology of science, and sociology of higher education and of innovation.

Gralf-Peter Calliess holds a Chair in Private Law, Comparative and International Economic Law, and Legal Theory at the Law Department of the University of Bremen. He is Director at ZenTra, the Centre for Transnational Studies of the Universities Bremen and Oldenburg (www. zen-tra.de). Together with Peer Zumbansen he has co-authored Rough Consensus \& Running Code: A Theory of Transnational Private Law (2010) and co-edited Law, Economics, and Evolutionary Theory (2011). He convened the Symposium on Transnational Corporations published in Indiana Journal of Global Legal Studies $(2011 ; 18(2))$.

Mats Forsgren is Professor Emeritus in International Business, Uppsala University, Permanent Visiting Professor at LUISS University, Rome, and Honorary doctor at Swedish School of Economics, Helsinki. His main research and teaching areas are foreign direct investment theory, theories of internationalization, managing the multinational firm and business network theory. He has published widely in journals including Strategic Management Journal, Journal of International Business Studies, Organization Studies, Journal of Management Studies, International Business Review and Management International Review. His latest book is Theories of the Multinational Firm - A Multidimensional Creature in the Global Economy (2013, second edition).

Jörg Freiling is currently employed as Head of LEMEX Chair in Small Business and Entrepreneurship, Faculty of Business Studies and Economics, University of Bremen. He received his habilitation at the Faculty for Business and Economics at the Ruhr University of Bochum (title of thesis 'Reorganization: A Resource-based View'). He was awarded his PhD by the University of Bochum (title of thesis 'Supplier's Dependence on Customers - A Strategic Problem'). His research focuses on governance of transnational companies, entrepreneurship and new 
venture failure, innovative business models, entrepreneurial thinking and real options, management of family businesses and competencebased theory.

Nathan S. Greidanus is an Assistant Professor in Business Administration at the Asper School of Business, University of Manitoba. His research and teaching are motivated by the desire to increase societal well-being through sustainable economic development. His research interests intersect the broad areas of entrepreneurship, international business strategy and sustainable development. His publications include articles in toptier academic journals such as the Journal of International Business Studies; book chapters, including the prestigious, The Accountable Corporation series; and book titled Growing the Virtual Workplace: The Integrative Value Proposition for Telework (2008).

Martin Heidenreich holds the Jean Monnet Chair for European Studies in Social Sciences and is Director of the Jean Monnet Centre for Europeanisation and Transnational Regulations at the University of Oldenburg. His research interests include regional and national patterns of employment, management and innovation and the Europeanization of national societies.

Jean-François Hennart holds positions at the University of Pavia, Queen's University Management School, and Singapore Management University, and is an Extramural Scholar at Tilburg University CentER. His research focuses on the comparative study of international economic institutions such as multinational firms, joint ventures and alliances, and modes of foreign market entry. His theory of multinational enterprise pioneered the application of transaction cost theory to international business. He is consulting editor for JIBS and Fellow of AIB and EIBA. His work has been published in the Journal of International Business Studies, Strategic Management Journal and Management Science.

Perttu Kähäri defended his doctoral dissertation at the Aalto University, School of Business (formerly known as Helsinki School of Economics) in 2014. His dissertation addresses the dynamics of regional headquarters with a longitudinal mixed method approach, with contributions to the knowledge on transnational corporations and their headquarters. Kähäri has 20 years of managerial experience in international business. He has previously worked as $\mathrm{CFO}$ and in various other management roles in DHL and in the Finnish Are Group. He has held roles in headquarters at global, regional and country level. 
Sven Laudien is Interim Full Professor at Otto von Guericke University Magdeburg, Faculty of Economics and Management, Chair in International Management. He received his $\mathrm{PhD}$ from the University of Bremen, Germany, and his Diploma in Business Administration from the Christian-Albrechts-University Kiel, Germany. His research focuses on formal and informal coordination of transnational business activities, service management and service innovation aspects, business model design, international entrepreneurship and strategic competence-based management.

Sarianna Lundan holds the Chair in International Management and Governance at the University of Bremen in Germany. She received her PhD from Rutgers University, and has held prior appointments at the University of Reading and Maastricht University. She has published widely in journals and books, and has co-authored the second edition of Multinational Enterprises and the Global Economy (2008) with John H. Dunning. She has also consulted extensively with the United Nations and the World Bank on issues related to the development impact of foreign investment.

Jannika Mattes is Junior Professor for the Sociology of European Societies at the University of Oldenburg, Germany. Her research interests lie at the intersection among innovation studies, organizational sociology and regional geography. In her PhD thesis titled 'Innovation in multinational companies: organisational, international and regional dilemmas', she investigated collaborative innovation projects in multinational companies. Jannika Mattes studied European Economic and Business Studies in Bamberg (Germany) and Granada (Spain) and completed her research stays in Uppsala (Sweden), London (UK) and Lund (Sweden).

Peter Muchlinski is Professor in International Commercial Law at the School of Oriental and African Studies (SOAS), University of London. He is the author of Multinational Enterprises and the Law (2007, second edition) and is co-editor (with Dr Federico Ortino and Professor Christoph Schreuer) of the Oxford Handbook of International Investment Law (2008). He acts as an adviser to UNCTAD on investment law issues. Until its dissolution in 2008, he was Co-Rapporteur to the International Law Association Committee on the International Law on Foreign Investment.

Guido Palazzo is Professor of Business Ethics at the University of Lausanne. He earned his degree at the University of Marburg in Germany 
(Dr. phil. 2000). His research interests are in corporate social responsibility, unethical decision making and organized crime.

Rebecca Piekkari is Professor of International Business at Aalto University, School of Business (formerly known as Helsinki School of Economics). Her research focuses on the challenges of managing multinational corporations and organizational design. More specifically, she has contributed to the stream of language in international business and the use of qualitative methods in international business and management research. Her work has been published in journals such as the Academy of Management Review, Journal of Management Studies, and Journal of International Business Studies as well as in several handbooks in the area.

Andreas Georg Scherer is Professor of Foundations of Business Administration and Theories of the Firm at the University of Zurich. He earned his degrees at the University of Erlangen Nürnberg (Dr. rer. pol. 1994; Dr. rer. pol. habil. 2000) and worked as a Professor at the University of Konstanz (Germany) from 2000 to 2002 . His research interests are in business ethics, corporate social responsibility, organization theory and philosophy of science.

Hannah Trittin, MA, is a research and teaching assistant at the University of Zurich, Switzerland. She earned a Magister Artium degree of political and economic science of the Friedrich-Alexander-University Erlangen-Nürnberg. Her research interests are in corporate communication, corporate social responsibility, organizational communication and social media.

Alain Verbeke is Professor of International Business Strategy and holds the McCaig Research Chair in Management at the Haskayne School of Business, University of Calgary (Canada). He was previously the Director of the MBA programme, Solvay Business School, University of Brussels (VUB, Belgium). He has also been a Visiting Professor at Dalhousie University, the University of Toronto and the Université Catholique de Louvain, as well as an Associate Fellow of Templeton College (University of Oxford) and an Academic Associate of the Centre for International Business and Management, Judge Business School, University of Cambridge. Dr. Verbeke is an elected Fellow of the Academy of International Business, and has served as JIBS Area Editor (MNE Theory and International Strategy). His widely used textbook is International Business Strategy: Rethinking the Foundations of Global Corporate Success (2013, second edition). 
Jan-Christoph Volckmer was a research associate at the Chair of Accounting and Control. His dissertation thesis was on the internationalization of auditing firms.

Stephan von Harder is a research associate and doctoral candidate at the Law Department of the University of Bremen. His dissertation thesis is on the law and economics of intra-firm trade and he conducted expert interviews in the field.

Jochen Zimmermann is Professor of Accounting at the University of Bremen where he holds the Chair of Accounting and Control. His research covers insurance accounting, accounting regulation and the interplay of accounting-based regulations with institutions such as auditing firms. 